\title{
Media Promosi Produk UMKM dengan Menggunakan EPIC Model
}

\author{
Gesty Ernestivita ${ }^{1}$, Subagyo² \\ gesty@unpkediri.ac.id'1, subagyo@unpkediri.ac.id² \\ Universitas Nusantara PGRI Kediri1,2
}

\begin{abstract}
MSMEs must be able to grow and develop in the era of global competition. The growth and development of MSME are shown by increasing sales volume and profitability. One of strategy to increase sales volume is promoting through social media, one of them is Instagram. This study aims to measure the effectiveness of using Instagram as a medium for promoting MSME products using the EPIC model. The study was conducted on 100 active Instagram owners who follow SMEs that promote their products through Instagram. Based on the EPIC Model, the most effective dimension is communication and it is included in a very effective scale range with a mean score of 4.14 .
\end{abstract}

Keywords: Effectivity, Promotion Media, Instagram, EPIC model, MSMEs

\begin{abstract}
Abstrak
UMKM harus mampu tumbuh dan berkembang di era persaingan global. Pertumbuhan dan perkembangan UMKM ditunjukkan dengan kenaikan volume penjualan dan perolehan laba. Salah satu strategi untuk meningkatkan volume penjulananadalah melakukan promosi melalui media sosial, salah satunya melalui Instagram. Penelitian ini bertujuan untuk mengukur efektivitas penggunaan instagram sebagai media promosi produk UMKM dengan menggunakan EPIC model. Penelitian dilakukan terhadap 100 pemilik Instagram aktif yang memfollow UMKM yang mempromosikan produknya melalui instagram. Berdasarkan EPIC Model, demensi yang paling efektif adalah komunikasi dan termasuk dalam rentang skala sangat efektif, yaitu dengan skor rerata 4,14 .
\end{abstract}

Kata Kunci: Efektivitas,Media Promosi, Instagram, EPIC model, UMKM

\section{PENDAHULUAN}

Usaha Mikro Kecil dan Menengah (UMKM) memberi kontribusi besar dalam perekonomian nasional. Kontribusi sektor UMKM sangat diharapkan guna menciptakan lapangan kerjaan dan pertumbuhan ekonomi, karena UMKM dirasasangat fleksibel dan dengan mudah dapat beradaptasi dengan perubahan pola permintaan pasar. Subagyo (2013) menyatakan bahwa peran UMKM dalam perekonomian Indonesiadapat ditinjau dari 4faktor berikut: (1) Sebagai pemain utama dalam perekonomian nasional, (2) Sebagai penyedia lapangan pekerjaan terbesar, (3) Memberi kontribusi yang besar terhadap Produk Domistik Bruto, dan (4) Memberi kontribusi terhadap peningkatan ekspor non migas.

Menurut dataKementerian Koperasi dan Usaha Kecil Menengah, selama lima tahun terakhir kontribusi sektor UMKM terhadap Produk Domestik Bruto (PDB) mengalami peningkatan dari 57,84 persen menjadi 60,34 persen.Demikian pula terdapat peningkatan dalam penyerapan tenaga kerja, yaitu dari 96,99 persen menjadi 97,22 persen.Dengan semakin banyaknya tenaga kerja yang diserap, hal ini berdampak pada meningkatnya pendapatan masyarakat. Hal tersebut mengindikasikan bahwa UMKM mampu berperan nyata dalam mengurangi kemiskinan dan pengangguran (CNN Indonesia, 2016). 


\section{Efektor, Volume 7 Issue 1, 2020, Pages 1 - 14 \\ Gesty Ernestivita, Subagyo}

Salah satu kota di Indonesia yang perkembangan jumlah UMKM nya pesat yaitu kota Kediri. Data Badan Pusat Statistik (BPS) mencatat, pada tahun 2011 kota Kediri memiliki 32 ribu UMKM, sedangkan tahun 2016 naik $17 \%$ menjadi 39 ribu unit usaha, yang sebagian besar bergerak di sektor industri makanan minuman dan industri kreatif (Radarkediri.jawapos, 2018).Berkembangan UMKM di Kota Kediri berkat program-program pemerintah dalam memotivasi dan menanamkan jiwa wirausaha kepada masyarakat, baik melalui sekolah, organisisi kepemudaan maupun kegiatan-kegiatan kemasyarakatan lainnya. Di samping mendorong tumbuhnya UMKM baru, pemerintah kota Kediri juga giat melakukan pembinaan UMKM melalui dinas yang membidangi, seperti Dinas Koperasi dan UMKM danDinas Perindustrian dan Perdagangan yang bersinergi dengan Perguruan Tinggi, Kamar Dagang dan Industri dan Business Developmen Centre (Subagyo, 2013).

Keberhasilan UMKM tidak hanya diharapkan oleh pelaku usaha, tetapi juga pemerintah. Keberhasilan UMKM, di satu sisi dapat mensejahterakan pemiliknya, di sisi lain dapat mengurangi pengangguran, mengurangi kemiskinan dan meningkatan perekonomian daerah. Salah satu indikator keberhasilan UMKM adalah meningkatnya volume penjualan usaha dari waktu ke waktu, dan mampu menjual produknya sesuai dengan target yang diinginkan. Melakukan promosi secara efektif adalah salah satu cara yang dapat dilakukukan oleh pelaku UMKM untuk dapat menaikkan volume penjualanbisnisnya.

Menurut Durianto, Sugiarto, Widjaja dan Supratikno (2003), efektivitas media promosi secara umum dapat diukur berdasarkan tiga kriteria, yaitu pengingatan, persuasi dan penjualan. Efektivitas media promosi terhadap omzet penjualan dapat dilihat dari catatan penjualan, sedangkan efektivitas promosi berdasarkan pengingatan dan persuasi dapat diukur dengan EPIC Model yang dikembangkan oleh AC. Nielson. EPIC Model memiliki empat demensi kritis, terdiri dari emphaty, persuation, impact dan communication. EPIC Model merupakan model yang efektif digunakan untuk melakukan evaluasi media promosi yang dilakukan terkait dengan kemampuannya mendapat perhatian, dipahami, menggugah perasaan dan mempengaruhi perilaku konsumen.

Efektivitas promosi juga dipengaruhi oleh pemilihan media promosi yang digunakan. Di era digital seperti saat ini, strategi yang efektifuntuk mempromosikan produkdengan biaya yang efisen adalah melalui media sosial, sepertinstagram, facebook, whatshap, dan twiter. Kotler (2009) berpendapat bahwa media sosial merupakan sarana bagi produsen untuk menyampaikan pesan kepada konsumen baik berupa teks, gambar, audio maupun video tentang produk yang ditawarkan. Lebih lanjut Sulianta (2014) bependapat bahwa media sosial memiliki kelebihan dibadingkan dengan media promosi tradisional.

Di antara beberapa media sosial yang pada umumnya digunakan oleh UMKM, instagram adalah media sosial yang paling banyak digunakan, termasuk pelaku UMKM di Kota Kediri. Gambar di bawah ini adalah beberapa contoh promosi yang dilakukan oleh UMKM di Kota Kediri melalui media instagram. 


\section{Efektor, Volume 7 Issue 1, 2020, Pages 1 - 14 \\ Gesty Ernestivita, Subagyo}

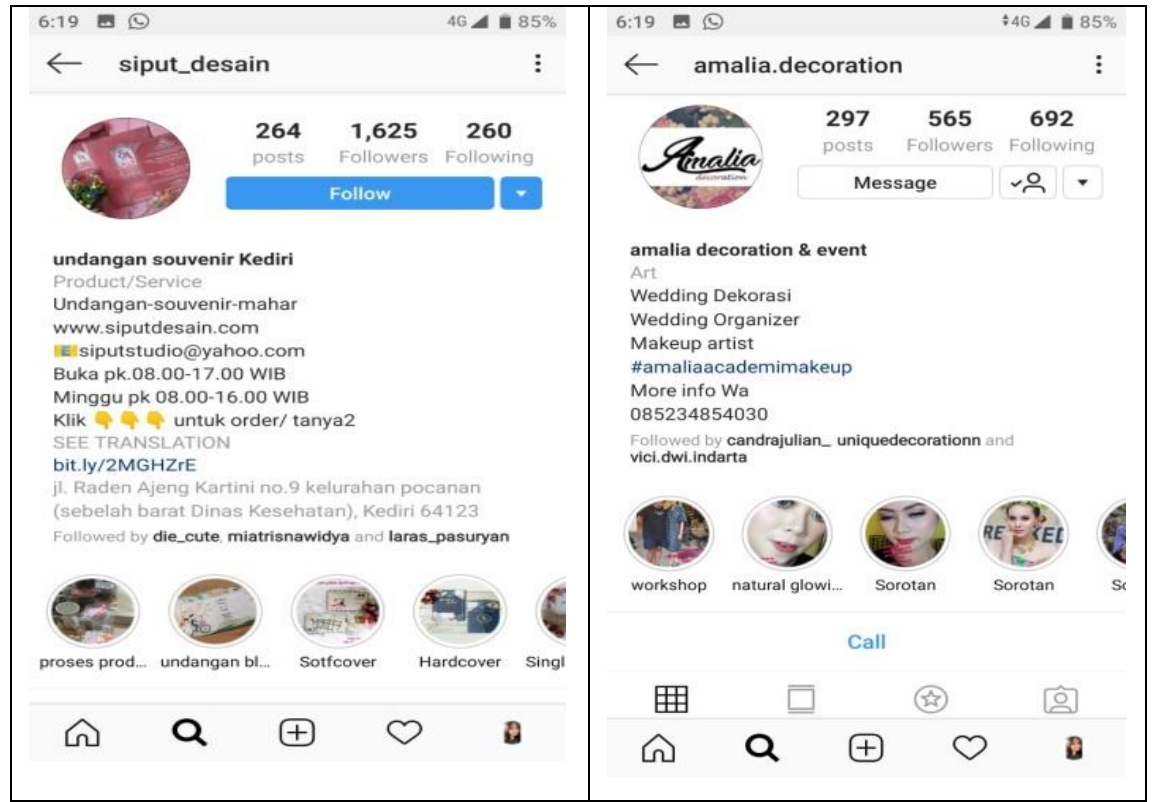

Gambar 1. Contoh Promosi produk UMKM melalui Instagram

Sumber: Instgram.com

Beberapa alasan mengapa instagram lebih banyak digunakan dibanding dengan media sosial lainnya menurut Diamond (2015), karena dalam instagram terdapat banyak usnsur pendukung yang sangat bermanfaat untuk promosi, seperti profil, hashtag (\#), followers, push notification dan tag lokation, yang kesemuanya dapat dihubungkan dengan jejaring sosial lain. Untuk itulah tidak heran jika saat ini instagram memiliki100 juta pengguna untuk berbagai kepentingan, mulai dari sosialisasi, promosi bisnis dan atau hanya sekedar mengikuti trend.

Hasil penelitian terkait dengan efektivitas penggunaan instagram dalam promosi dan EPIC model sebagai pengukur efektivitas promosi telah dilakukan oleh beberapa peneliti terdahulu. Andini (2013) dalam penelitiannya menyatakan bahwa instagram efektif digunakan untuk promosi, karenapenggunaan instagram didukung oleh kekuatanmulut ke mulutyang memengaruhi konsumen memutuskan pembelian. Hasil penelitian Hasanah, Nugroho dan Nugroho (2015) dengan menggunkan EPIC model menyatakan bahwa iklan jejaring sosial fanpage merupan media promosi yang efektif untuk mempromosikan tempat wisata Huma Harati Kalteng.

Mendasarkan pada latar belakang di atas, penelitian ini bertujuan untuk mengukur efektivitas penggunaan instragram sebagai media promosi produk UMKM di kota Kediri dengan menggunakan EPIC model.

\section{KERANGKA TEORI}

Salah satu komponen yang menjadi prioritas dalam pemasaran adalah promosi. Rangkuti (2009) menyatakan bahwa promosi merupakan suatu unsur dalam bauran pemasaran yang didayagunakan untuk memberitahukan, membujuk, dan mengingatkan tentang produk perusahaan. Promosi merupakan suatu bentuk komunikasi dalam pemasaran. Tujuan promosi menurut Kotler dan Amstrong (2012) yaitu meningkatkan volume penjualan, mendorong konsumen malakukan pembelian dan mendapatkan pelanggan baru. 


\section{Efektor, Volume 7 Issue 1, 2020, Pages 1 - 14 \\ Gesty Ernestivita, Subagyo}

Promosi harus dilakukan seefektif mungkin.Promosi dikatakan efektif jika hasil yang dicapai sesuai dengan yang diharapkan.Menurut Cannon, Perreault, danMcCarthy (2009) promosi dikatakan efektif jika memenuhi kriteria: (1) media promosi yang digubakan sesuai dengan strategi pemasaran yang ditetapkan, (2) tujuan dilakukannya promosi jelas (3) sasaran pasar yang dijangkau jelas, (4) dana tersedia sesuai kebutuhan, dan (5) siapa yang dijangkau jelas. Kotler dan Keller (2009)berpendapat bahwa promosi yang baik dan efektif haruslah mengandung pesan ideal yang menarik perhatian calonkonsumen, memunculkan rasa keingintahuan lebih lanjut, menimbulkan keinginan membeli, dan membangkitkan tindakan pembelian.

Efektivitas atau tidaknya promosi dapat diketahui melalui pengukuran terhadap promosi yang dilakukan. EPIC model merupakan suatu model yang cocok dipergunakan untuk mengukur efektivitas promosi. Rangkuti (2008) mengungkapkan bahwa EPIC modelyang dicetuskan oleh AC Nielsena (sebuah perusahaan peneliti pemasaran yang memiliki reputasi kelas dunia), memiliki empat dimensi kritis, yaitu: empati (empathy), persuasi (persuation), dampak (impact) dan komunikasi (comunication).EPIC Model memiliki keunggulan dalam mengukur efektivitas promosi dibandingkan dengan model lainnya. Kelebihan dari EPIC model adalah ke empat demensi yang dimiliki dapat diukur secara terpisah, sehingga ketika suatu perusahaan ingin mengatasi satu saja kelemahan yang terdeteksi kurang efektif dapat dilakukan.

Empat dimensi kritis yang diukur dalam EPICModel dideskripsikan sebagai berikut:

a. Empati (Empathy)

Empati merupakan pemberian informasi tentang daya tarik suatu merek, informasi yang sifatnya berharga serta melibatkan afeksi dan kognisi. Peter dan Jerry (2009) menyatakan bahwa afeksi dan kognisi mengacu pada suatu tanggapan inernal psikologis yang dimiliki oleh pembeli terhadap suatu rangsangan dari lingkungan atau kejadian yang berlangsung. Afeksi melibatkan perasaan sedangkan kognisi melibatkan pamikiran. Tanggapan afektif memiliki variasi yang berupa suatu penilaian positif atau negatif maupun menyenangkan atau tidak menyenangkan.

b. Dimensi Persuasi (Persuation)

Setiadi (2010) mengemukakan bahwa persuasi adalah suatu usaha yang dilakukan perusahaan untuk mendorong target konsumen agar merubah perilakunya, keyakinannya, dan sikapnya atas kemauan sendiri yang dapat dicapai dengan memanfaatkan pengaruh verbal dan non verbal. Durianto dkk. (2003) menyatakan bahwa persuasi adalah berubahnya suatu kepercayaan,sikap dan keinginan berperilaku yang disebabkan suatu kegiatan komunikasi promosi.

C. Dimensi Dampak (Impact)

Dimensi impactmenjelaskan apakah suatu brand atau merek terlihat lebih menonjol dibandingkan merek pesaingnya pada kategori yang sejenis, dan apakah merek tersebut mampu melibatkan konsumen dalam pesan yang telah disampaikan. Timbal balik yang diharapkan dari 


\section{Efektor, Volume 7 Issue 1, 2020, Pages 1 - 14 \\ Gesty Ernestivita, Subagyo}

kegiatan tersebut adalah seberapa besar pengetahuan terhadap produk (product knowledge) melalui tingkat keterlibatan konsumen (involment) dalam proses pemilihan.

Durianto dkk. (2003) berpendapat bahwa dampak dari kegiatan promosi yang diinginkan product knowledge yang telah dijelaskan sebelumnya adalah jumlah penetahuan produk yang dicapai konsumen melalui tingkat keterlibatan konsumen dalam pengambilan keputusan membeli. Konsumen dapat melakukan pemilihan tiga jenis pengetahuan produk, yakni: pengetahuan tentang karakter produk, konsekuensi dan manfaat positif menggunkan produk, serta kepuasan terhadap suatu produk.

d. Dimensi Komunikasi (Comunication)

Durianto dkk. (2003) menyatakan bahwa dimensi komunikasi mampu memberikan suatu informasi tentang kehandalan konsumen dalam mengingat pesan yang disampaikan suatu merek, pemahaman serta kekuatan kesan yang ditinggalkan pesan tersebut. Kennedy dan Soemanagara (2006) mencetuskan empat pedoman untuk menyusun pesan dalam bentuk tulisan, yaitu:

1) Subjek dan tujuan penulisan pesan haruslah jelas

2) Informasi yang tertulis harus menunjukkan adanya hubungan antara subjek dengan tujuan penyampaian pesan

3) Gagasan dalam pesan dikelompokkan dan ditampilkan dengan logis

4) Seluruh tulisan dalam pesan telah mencakup informasi yang akan disampaikan kepada konsumen.

\section{KERANGKA BERFIKIR}

Promosi adalah faktor penting dalam proses bisnis. Promosi bertujuan memberi informasi kepada target pasar, sehingga orang mau memperhatikan, mengingat dan akhirnya melakukan pembelian(Shimp, 2003).

Untuk mengukur efektivitas promosi banyak model yang bisa digunakan, antara lain CDM (Consumer Decision Model), CRI (Customer Response Index), DRM (Direct Rating Method), dan EPIC (Emphaty, Persuation, Impact and Comuunication) model. Dalam penelitian ini yang digunakan untuk mengukur efektivitas promosi produk UMKM melalui instagram adalah EPICmodel. Sebagai pertimbangan pemilihan EPICmodel dibanding dengan yang lain adalah EPIC model memisahkan empat demensi kritis sebuah promosi, yaitu dimensi emphathy, persuation, impact and comuunication. Dengan mendasarkan pada kajian penelitian terdahulu, berikut adalah kerangka penelitian. 


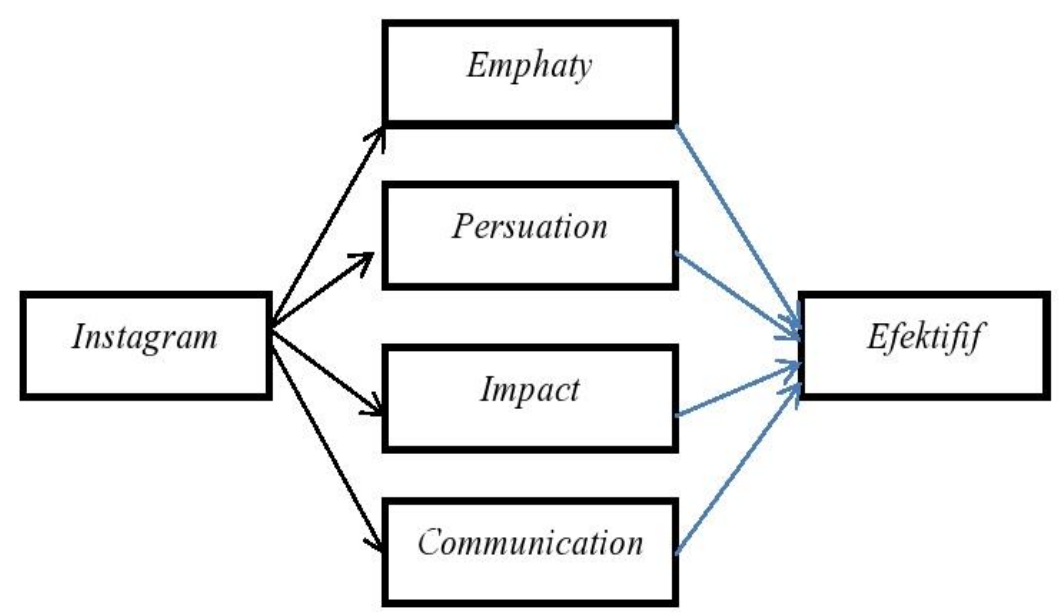

Gambar 2. Kerangka Penelitian

\section{METODE PENELITIAN}

Penelitian ini termasuk jenis penelitian eksplanatif dengan pendekatan kuantitatif. Sebagai subjek penelitian adalah pengguna Instagram aktif yang menjadi follower UMKM. Obyek penelitian adalah media promosi instagram yang digunakan oleh UMKM di Kota Kediri dalam mempromosikan produknya.

Jumlah populasa dalam penelitian ini tidak terbatas, yaitusemua akun instagram aktif yang menjadi followerUMKM Kediri. Untuk sampel ditentukan sebanyak 100 pemilik akun instagram aktif dan memfollowpaling sedikit satu akun UMKMdi kota Kediri yang diambil dengan menggunakan teknik accidental sampling.

Untuk mendapatkan data dari reponden terkait dengan dimensi EPIC (Emphaty, Persuation, Impact dan Comunication) dilakukan dengan mengirim angket langsung ke alamat instagram responden. Indikator dari masingmasing demensi EPIC sebagai-berikut:

Tabel 1. Demensi, Indikator dan Item Pertanyaan

\begin{tabular}{|c|c|c|}
\hline DEMENSI & INDIKATOR & ITEM \\
\hline Emphaty & $\begin{array}{l}\text { 1. Baik tidaknya media promosi } \\
\text { yang disampaikan berdasarkan } \\
\text { pemikiran (kognisi) } \\
\text { 2. Kesukaan terhadap iklan yang } \\
\text { disampaikan berdasarkan } \\
\text { perasaan (Afeksi) }\end{array}$ & $\begin{array}{l}\text { 1. Media promosi produk UMKM melalui IG } \\
\text { mudah dimengerti } \\
\text { 2. Menggunakan hastag (\#) yang sesuai } \\
\text { dengan produk sehingga produk mudah } \\
\text { terkategori } \\
\text { 3. Media promosi produk UMKM melalui IG } \\
\text { mudah diingat } \\
\text { 4. Media promosi produk UMKM } \\
\text { menggunakan artis endorse sehingga } \\
\text { lebih mudah mengerti deskripsi produk }\end{array}$ \\
\hline Persuation & 1. Ketertarikan pada media promosi & $\begin{array}{l}\text { 1. Media promosi produk UMKM melalui IG } \\
\text { menarik dan dapat meyakinkan konsumen } \\
\text { 2. Promosi produk UMKM tidak hanya } \\
\text { menggunakan gambar namun juga video } \\
\text { sehingga membuat lebih tertariki untuk } \\
\text { membeli. }\end{array}$ \\
\hline
\end{tabular}




\section{Efektor, Volume 7 Issue 1, 2020, Pages 1 - 14}

Gesty Ernestivita, Subagyo

\begin{tabular}{|c|c|c|}
\hline & 2. Media promosi dapat dipercaya & $\begin{array}{l}\text { 3. Media promosi produk UMKM melalui IG } \\
\text { dapat dipercaya, karena sesuai dengan } \\
\text { kenyataan } \\
\text { 4. Gambar yang ditampilkan sesuai dengan } \\
\text { produk asli }\end{array}$ \\
\hline Impact & $\begin{array}{l}\text { 1. Media promosi yang digunakan } \\
\text { tampil beda } \\
\text { 2. Pengetahuan terhadap produk } \\
\text { yang diiklankan }\end{array}$ & $\begin{array}{l}\text { 1. Media promosi produk UMKM melalui IG } \\
\text { kreatif, inovatif dan tampil beda, sehingga } \\
\text { menarik konsumen } \\
\text { 2. Media promosi menggunakan tema post } \\
\text { yang menarik sesuai dengan produk } \\
\text { UMKM yang dijual. } \\
\text { 3. Media promosi produk UMKM melalui IG } \\
\text { dapat memberikan pengetahuan kepada } \\
\text { konsumen tentang fungsi/manfaat produk } \\
\text { 4. Produk UMKM menyertakan hastag (\#) } \\
\text { yang sesuai di setiap postingan untu } \\
\text { mempermudah konsumen mencari } \\
\text { katalog produk }\end{array}$ \\
\hline Communication & $\begin{array}{l}\text { 1. Pemahaman terhadap kata yang } \\
\text { dituliskan } \\
\text { 2. Pemahaman terhadap gambar } \\
\text { yang ditampilkan }\end{array}$ & $\begin{array}{l}\text { 1. Media promosi IG dari produk UMKM } \\
\text { dengan jelas menyampaikan informasi } \\
\text { dan manfaat produk. } \\
\text { 2. Setiap postingan produk UMKM di IG } \\
\text { menyertakan keterangan lanjutan berupa } \\
\text { video untuk memperjelas deskripsi produk } \\
\text { UMKM dalam kolom deskripsi } \\
\text { 3. Gambar/tampilan produk UMKM yang } \\
\text { dipromosikan melalui IG mampu } \\
\text { menyampaikan isi dari pesan gambar. } \\
\text { 4. Gambar produk UMKM yang ditampilkan } \\
\text { merupakan real picture dan beresolusi } \\
\text { tinggi sehingga terlihat lebih jelas. }\end{array}$ \\
\hline
\end{tabular}

Selanjutnya, untuk mengetahui efektivitas instagram sebagai media promosi UMKMdianalisis dengan menggunakan EPIC model. Adapun langkah-langkah yang dilakukan untuk melakukan analisis EPIC mode/menurut Durianto dkk (2003) sebagai-berikut:

1. Menghitung rata-rata terbobot.

Rumus:

$$
X=\frac{\sum x i . f i}{N} \times 100 \%
$$

Dimana:

$X \quad=$ Rata-rata berbobot

$\sum x i . f i=$ Jumlah perkalian bobot dan frekuensi

$\mathrm{N} \quad=$ Jumlah responden 
2. Menghitung rentang skala

Rentang skala dihitung dengan menggunakan rumus sebagai-berikut:

$$
R S=\frac{R(b o b o t)}{M}
$$

Dimana:

$R($ bobot $) \quad=$ Bobot terbesar - Bobot terkecil

$M \quad$ = Banyaknya kategori bobot

Dengan menggunakan rumus di atas diperoleh rentang skala 0,8 , yang diperoleh dari:

$$
R S=\frac{(5-1)}{5}=0,8
$$

Dari perhitungan tersebut, selanjutnya posisi keputusan dinyatakan pada gambar berikut:

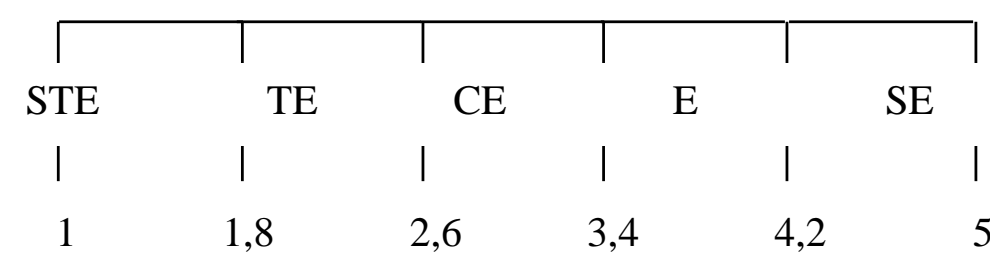

Gambar 3. Rentang Skala Keputusan

3. Menenentukan EPIC Rate

Angka EPIC rate mencerminkan posisi efektivitas promosi melalui Instagram menurut persepsi responden. Rumus dalam menentukan EPIC rate sebagai-berikut:

$$
\text { EPIC Rate }=\frac{X E+X P+X I+X C}{N}
$$

Keterangan:

$\mathrm{XE} \quad=$ Rata-rata demensi emphaty

$\mathrm{XP} \quad=$ rata-rata demensi persuation

$\mathrm{XI} \quad=$ rata-rata demensi impact

$\mathrm{XC} \quad=$ rata-rata demensi communication

\section{HASIL PENELITIAN DAN PEMBAHASAN}

Hasil pengujian terhadap 100 angket, yang terdiri dari atas 16 item pertanyaan menunjukkan nilai r hitung $>r$ tabel, sedangkan koifesien Cronbach alpha $>0,60$. Oleh karena semua instrumen memiliki nilai $r$ hitung $>r$ tabel, dan memiliki koefisien Cronbach alpha> 0,60, maka instrument dinyatakan valid dan reliabel.

Hasil uji validitas dan reliabilitas secara lengkap sebagaimana disajikan pada tabel 2 berikut. 
Efektor, Volume 7 Issue 1, 2020, Pages 1 - 14

Gesty Ernestivita, Subagyo

Tabel 2. Hasil Perhitungan Uji Validitas dan Realibilitas

\begin{tabular}{|c|c|c|c|c|}
\hline \multirow[t]{2}{*}{ Dimensi } & \multirow[t]{2}{*}{ Item } & \multicolumn{2}{|c|}{ Validitas } & \multirow{2}{*}{$\begin{array}{c}\text { Korelasi } \\
\text { Alpha }\end{array}$} \\
\hline & & T table & $\mathrm{R}$ hitung & \\
\hline \multirow[t]{4}{*}{ Empathy ( E ) } & E1 & 0,195 & 0,747 & \multirow[t]{4}{*}{0,822} \\
\hline & E2 & 0,195 & 0,678 & \\
\hline & E3 & 0,195 & 0,765 & \\
\hline & E4 & 0,195 & 0,786 & \\
\hline \multirow[t]{4}{*}{ Persuation ( P ) } & $\mathrm{P} 1$ & 0,195 & 0,742 & \multirow[t]{4}{*}{0,748} \\
\hline & P2 & 0,195 & 0,761 & \\
\hline & P3 & 0,195 & 0,681 & \\
\hline & P4 & 0,195 & 0,704 & \\
\hline \multirow[t]{4}{*}{ Impact (I) } & 11 & 0,195 & 0,688 & \multirow[t]{4}{*}{0,764} \\
\hline & 12 & 0,195 & 0,724 & \\
\hline & 13 & 0,195 & 0,666 & \\
\hline & 14 & 0,195 & 0,723 & \\
\hline \multirow[t]{4}{*}{ Communication (C) } & C1 & 0,195 & 0.823 & \multirow[t]{4}{*}{0,856} \\
\hline & $\mathrm{C} 2$ & 0,195 & 0,790 & \\
\hline & C3 & 0,195 & 0,787 & \\
\hline & C4 & 0,195 & 0.692 & \\
\hline
\end{tabular}

Selajutnya, untuk mengetahui EPICrate perlu mengetahui hasil jawaban responden berdasarkan angket yang telah diisi oleh 100 responden yang dikirim langsung melalui instagram responden. Tabel 3 menyajikan distribusi frekuensi indikator dimensi EPIC.

Tabel 3. Distribusi Frekuensi Indikator Dimensi EPIC

\begin{tabular}{|c|c|c|c|c|c|c|c|c|c|c|c|c|}
\hline \multirow[b]{2}{*}{ DEMENSI } & \multicolumn{2}{|c|}{ STS } & \multicolumn{2}{|c|}{ TS } & \multicolumn{2}{|c|}{$\mathrm{N}$} & \multicolumn{2}{|c|}{$S$} & \multicolumn{2}{|c|}{ SS } & \multicolumn{2}{|c|}{ TOTAL } \\
\hline & $\mathrm{Jlh}$ & $\%$ & Jlh & $\%$ & Jlh & $\%$ & Jlh & $\%$ & Jlh & $\%$ & $\mathrm{Jlh}$ & $\%$ \\
\hline \multicolumn{13}{|l|}{ EMPHATY } \\
\hline E1 & 0 & 0 & 8 & 8 & 17 & 17 & 54 & 54 & 21 & 21 & 100 & 100 \\
\hline E2 & 0 & 0 & 5 & 5 & 19 & 19 & 51 & 51 & 25 & 25 & 100 & 100 \\
\hline E3 & 0 & 0 & 5 & 5 & 18 & 18 & 53 & 53 & 24 & 24 & 100 & 100 \\
\hline E4 & 0 & 0 & 6 & 6 & 14 & 14 & 48 & 48 & 32 & 32 & 100 & 100 \\
\hline \multicolumn{13}{|l|}{ PERSUATION ( P ) } \\
\hline P1 & 1 & 1 & 14 & 14 & 33 & 33 & 38 & 38 & 14 & 14 & 100 & 100 \\
\hline P2 & 0 & 0 & 12 & 12 & 35 & 35 & 42 & 42 & 11 & 11 & 100 & 100 \\
\hline P3 & 0 & 0 & 10 & 10 & 26 & 26 & 45 & 45 & 19 & 19 & 100 & 100 \\
\hline P4 & 0 & 0 & 12 & 12 & 31 & 31 & 40 & 40 & 17 & 17 & 100 & 100 \\
\hline \multicolumn{13}{|l|}{ IMPACT (I) } \\
\hline 11 & 0 & 0 & 18 & 18 & 26 & 26 & 42 & 42 & 14 & 14 & 100 & 100 \\
\hline 12 & 1 & 1 & 13 & 13 & 27 & 27 & 46 & 46 & 13 & 13 & 100 & 100 \\
\hline 13 & 0 & 0 & 12 & 12 & 31 & 31 & 44 & 44 & 13 & 13 & 100 & 100 \\
\hline 14 & 0 & 1 & 14 & 14 & 33 & 33 & 40 & 40 & 13 & 13 & 100 & 100 \\
\hline \multicolumn{13}{|l|}{$\begin{array}{l}\text { COMMUNICATION } \\
\text { (C) }\end{array}$} \\
\hline C1 & 0 & 0 & 2 & 2 & 12 & 12 & 50 & 50 & 36 & 36 & 100 & 100 \\
\hline $\mathrm{C} 2$ & 0 & 0 & 0 & 0 & 17 & 17 & 43 & 43 & 40 & 40 & 100 & 100 \\
\hline $\mathrm{C} 3$ & 0 & 0 & 4 & 4 & 16 & 16 & 47 & 47 & 33 & 33 & 100 & 100 \\
\hline C4 & 0 & 0 & 6 & 6 & 14 & 14 & 50 & 50 & 30 & 30 & 100 & 100 \\
\hline
\end{tabular}


Berdasarkan distribusi frekuensi indikator dimensi EPIC, selanjutnya EPIC Rate dapat dihitung dengan langkah-langkah sebagai berikut:

1. Menghitung skor rata-rata demensi emphaty

$$
\begin{aligned}
& \mathrm{E} 1=\frac{(1 \times 0)+(2 X 8)+(3 \times 17)+(4 X 54)+(5 X 21)}{100}=\frac{388}{100}=3,88 \\
& E 2=\frac{(1 X 0)+(2 X 5)+(3 X 19)+(4 X 51)+(5 X 25)}{100}=\frac{396}{100}=3,96 \\
& \mathrm{E} 3=\frac{(1 \times 0)+(2 \times 5)+(3 \times 18)+(4 \times 53)+(5 \times 24)}{100}=\frac{396}{100}=3,96 \\
& E 4=\frac{(1 X 0)+(2 X 6)+(3 \times 14)+(4 X 48)+(5 \times 32)}{100}=\frac{406}{100}=4,06 \\
& \bar{x} E=\frac{3,88+3,96+3,96+4,06}{4}=3,96
\end{aligned}
$$

2. Menghitung skor rata-rata demensi persuation

$$
\begin{aligned}
& \mathrm{P} 1=\frac{(1 X 1)+(2 X 14)+(3 X 33)+(4 X 38)+(5 X 14))}{100}=\frac{350}{100}=3,50 \\
& \mathrm{P} 2=\frac{(1 X 0)+(2 X 12)+(3 X 35)+(4 X 42)+(5 X 11)}{100}=\frac{352}{100}=3,52 \\
& \mathrm{P} 3=\frac{(1 X 0)+(2 X 10)+(3 X 26)+(4 X 45)+(5 X 19)}{100}=\frac{373}{100}=3,73 \\
& \mathrm{P} 4=\frac{(1 X 0)+(2 X 12)+(3 X 31)+(4 X 40)+(5 X 17)}{100}=\frac{362}{100}=3,62 \\
& \bar{X} \mathrm{P}=\frac{350+3,52+3.73+3,62}{4}=3,59
\end{aligned}
$$

3. Menghitung skor rata-rata demensiimpact

$$
\begin{aligned}
& 11=\frac{(1 X 0)+(2 X 18)+(3 X 12)+(4 X 542)+(5 X 14)}{100}=\frac{352}{100}=3,52 \\
& 12=\frac{(1 X 1)+(2 X 13)+(3 X 27)+(4 X 46)+(5 X 43)}{100}=\frac{357}{100}=3,57 \\
& 13=\frac{(1 X 0)+(2 X 12)+(3 X 31)+(4 X 44)+(5 X 13)}{100}=\frac{358}{100}=3,58 \\
& 14=\frac{(1 X 0)+(2 X 14)+(3 X 33)+(4 X 40)+(5 X 13)}{100}=\frac{352}{100}=3,52 \\
& \bar{x} \mid=\frac{3,52+357+3,58+3,52}{4}=3,55
\end{aligned}
$$

4. Menghitung skor rata-rata demensi communication

$$
\begin{aligned}
& \text { C1 }=\frac{(1 X 0)+(2 X 2)+(3 X 12)+(4 X 50)+(5 X 36)}{100}=\frac{420}{100}=4,20 \\
& C 2=\frac{(1 X 0)+(2 X 0)+(3 X 17)+(4 X 43)+(5 X 40))}{100}=\frac{423}{100}=4,23 \\
& C 3=\frac{(1 X 0)+(2 X 4)+(3 X 16)+(4 X 47)+(5 X 33)}{100}=\frac{409}{100}=4,09
\end{aligned}
$$


$C 4=\frac{(1 X 0)+(2 X 6)+(3 X 14)+(4 X 50)+(5 X 30)}{100}=\frac{404}{100}=4,04$

$\bar{x} \mathrm{C}=\frac{4,20+4,23+4,09+4,04}{4}=4,14$

5. Menghitung EPIC Rate

$$
\text { EPIC Rate }=\frac{3,97+3,59+3,55+4,14}{4}=3,81
$$

Nilai EPICrate sebesar 3,81, hal ini menunjukkan media promosi yang dilakukan melalui instragram oleh UMKM di Kota Kediri efektif, karena di rentang3,41 - 4,21. Jika dinyatakan dalam gambar, nilai rata-rata ke empat dimensi EPIC dapat dilihat pada gambar 3 berikut.

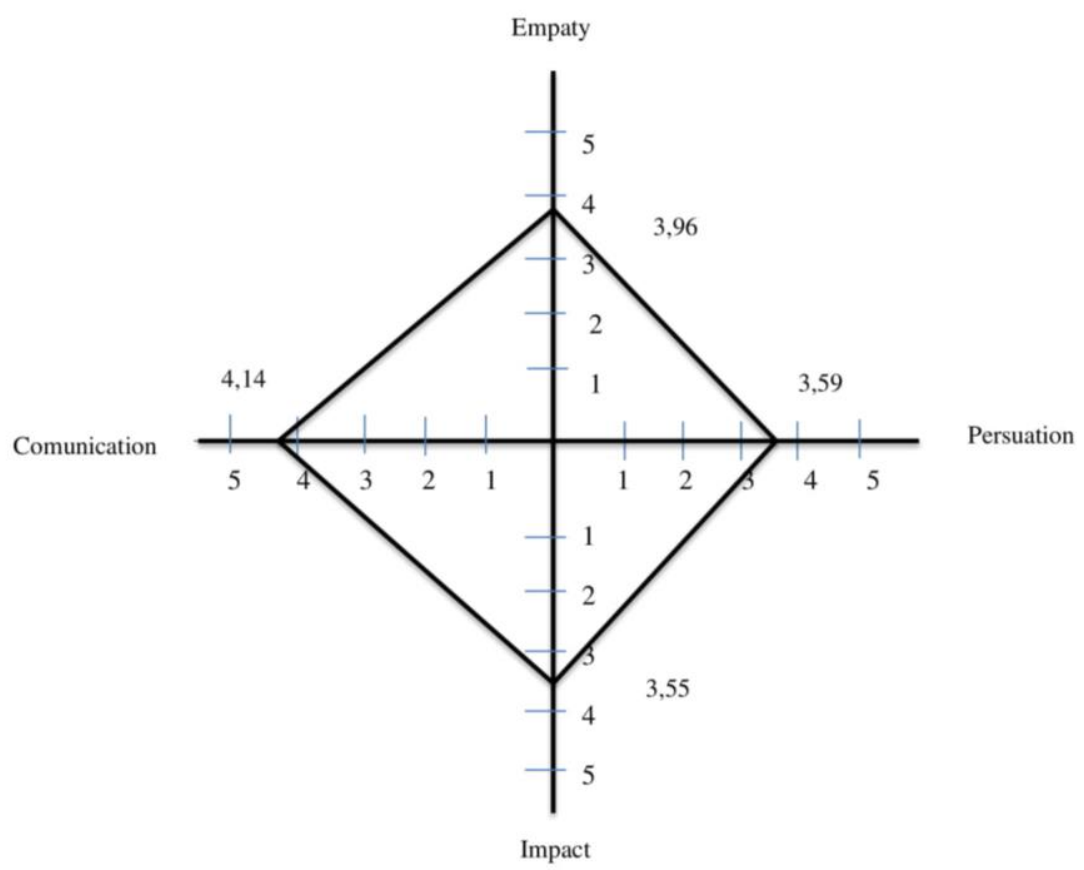

Gambar 3. Hasil Perhitungan EPIC Rate

Dimensi communication (komunikasi) memiliki skor rata-rata sebesar 4,14. Hal ini memberi makna bahwa ditinjau dari demensi communication, UMKM sudah mampu menarik perhatian konsumennya melalui promosi yang dilakukan di instagram. Komunikasi yang dilakukan meliputi pemberian informasi pada gambar yang sudah sangat sesuai dengan deskripsi dari setiap foto produk yang diposting. Komunikasi merupakan hal yang penting dalam penjualan online, karena penjualan onlinemerupakan penjualan produk yang dilakukan hanya dengan berupa gambar produk, sehingga kolom deskripsi produk adalah salah satu cara penjual untuk berkomunikasi dengan pembeli secara tertulis.Dimensi communication memiliki nilai komulatif rata-rata paling tinggi, hal ini menunjukkan 


\section{Efektor, Volume 7 Issue 1, 2020, Pages 1 - 14 \\ Gesty Ernestivita, Subagyo}

bahwa communication merupakan demensi yang paling efektif dibandingkan dengan ke tiga dimensi lain. Hasil penelitian ini memberi informasi bahwa dalam melakukan promosi melalui media instagram, pelaku usaha perlu menyampaikan informasi dengan jelas tentang produk, disamping itu penggunaan gambar dalam media promosi instagram harus bisa tersampaikan kepada konsumen dengan baik.

Dimensi Emphaty (empati) memiliki skor rata-rata sebesar 3,96. Hal ini memberi makna bahwaditinjau dari demensi emphaty, promosi yang dilakukan UMKM melalui media instagram sudah baik berdasarkan pemikiran dan perasaan para konsumen dan pelanggan. Responden merasakan media promosi produk UMKM melalui Instagram kontennya mudah dimengerti, produk mudah terkategori karena menggunakan hashtag (\#), produk mudah diingat, apalagi menggunakan figur publik endors. Hal ini dapat terwujud karena kata-kata dalam kolom deskripsi dan gambar yang ditampilkan dalam instagram mampu memunculkan emosional konsumen dan pelanggan.

Dimensi persuation (persuasi) memiliki skor rata-rata sebesar 3,59. Hal ini memberi makna bahwa ditinjau dari demensi persuasi, promosi yang dilakukan UMKM melalui Instagram telah mampu menarik perhatian dan mampu dipercaya oleh responden untuk membeli produk yang ditawarkan. Promosi yang dilakukan mampu meyakinkan konsumen, karena tidak hanya menggunakan gambar, tetapi juga video sehingga mampu mempengaruhi minat responden untuk membeli produk yang sudah dipromosikan.

Dimensi impact (dampak)memiliki skor rata-rata sebesar 3,55. Hal ini memberi makna bahwa ditinjau dari demensi impact, media promosi instagram oleh UMKM ditampilkan dengan konten yang kreatif, inovatif sesuai dengan tema dan tampil beda dibandingkan dnegan iklan bisnis yang lain, sehingga dapat menarik konsumen. $\mathrm{Di}$ samping itu, promosi yang dilakukan mampu memberi pengetahuan kepada konsumen tentang funngsi/manfaat produk, apalagi disertai dengan hashtag (\#) dalam setiap postingan, sehingga mempermudah konsumen untuk mencari katalog produk.

\section{SIMPULAN DAN SARAN}

Berdasarkan perhitungan dengan menggunakan EPICmodel, media promosi melaluiinstagram yang dilakukan oleh UMKM kota Kediri terbukti efektif, hal ini ditunjukkan oleh nilai rata-rata ke empat demensi EPIC (Emphaty, Persuation, Impact and Communiation) padarangedi atas 3,41. Demikian pula EPIC range menunjukkan angka 3,81 , berada pada range $3,41-4,21$ yang berarti promosi yang dilakukan oleh UMKM di Kediri melalui instagram termasuk kategori efektif.

Dari ke empat dimensi EPICmodel, communication merupakan dimensi yang paling efektif, dengan skor tertinggi yaitu 4,14. Hal tersebut dikarenakan pesan yang disampaikan melalui instagram jelas, dan gambar yang disajikan dapat dipahami oleh konsumen.

Berdasarkan analisis EPIC, promosi melalui instagram yang dilakukan oleh UMKM terbukri efektif, untuk itu para pelaku UMKM di kota Kediri perlu terus mempertahankan pengunaan instagram sebagai media promosi, karena mampu mempengaruhi konsumen dalam memelimproduk yang ditawarkan. 


\section{Efektor, Volume 7 Issue 1, 2020, Pages 1 - 14 \\ Gesty Ernestivita, Subagyo}

Communication merupakan dimensi yang paling efektif, maka pelaku UMKM di Kota Kediri hendaknya dalam melakukan promosi melalui instagram lebih memperhatikan demensi communication, karena pesan dan gambar yang disampaikan tentang produk lebih jelas dan mudah dipahami oleh konsumen.

\section{DAFTAR PUSTAKA}

Andini, N.P. (2013). "Pengaruh Viral Marketing terhadap Kepercayaan Pe;anggan dan Keputusan Pembelian (Studi pada mahasiswa Fakultas IImu Administrasi Universitas Brawijaya Angkatan 2013 yang Melakukan Pembelian Online Melalui Media Sosial Instagram). Jurnal Administrasi Bisnis (JAB), 11(1), 1-6.

Cannon JP., Perreault Wiliiam D., danMcCarthy E. Jerome. (2009).Pemasaran DasarPendekatan Manajerial Global. Buku 2 Edisi 16. Jakarta. Salemba Empat

CNN Indonesia.(2016). Kontribusi UMKM Terhadap PDB Tembus Lebih Dari 60 Persen. https://www.cnnindonesia.com/ekonomi/20161121122525-92-174080/kontribusi-umkm-terhadap-pdbtembus-lebih-dari-60-persen(diakses pada Tanggal 3 Maret 2019).

Diamond, Stephanie. (2015). The Visual Marketing Revolution 20 Kiat Sukses Pemasaran di Media Sosial. Jakarta: Serambi IImu Semesta

Durianto, Darmadi., Sugiarto., Widjaja, Anton,Wachidin, dan Supratikno, Hendrawan. (2003). Inovasi Pasar dengan Iklan yang Efektif: Strategi, Program, dan Teknik Pengukuran. Jakarta. PT Gramedia Pustaka Utama

Hasanah Nur, Nugroho Lukito Edi dan Nugroho Eko. (2015). "Analisis Efektivitas Iklan Jejaring Sosial sebagai Media Promosi Menggunakan EPIC Model”. Scientific Journal of Informatics.2(2), 99-109.

Kennedy, J.E. \& Soemanagara, R.D. (2009). Marketing Communication: Taktik dan Strategi. Jakarta. Bhuana IImu Populer.

Kotler, P. (2009). Manajemen Pemasaran. Jakarta. PT Index Kelompok Gramedia.

Kotler, P dan Amstrong, G (2012). Prinsip-Prinsip Pemasaran Edisi 13 Jilid 1. Jakarta: Erlangga

Kotler, Philip dan Kevin Lane Keller. (2009). Manajemen Pemasaran, Jilid I. Jakarta: Indeks.

Peter, J.Paul and Jerry C. Olson. (2009). Consumer Behavior and Marketing Strategy. 9 edition. McGraw-Hill Education.

Radarkediri.jawapos. (2018) Puluhan Ribu UMKM Tumbuh dan Berkembang di Kota Kediri. https://radarkediri.jawapos.com/read/2018/11/27/105647/puluhan-ribu-umkm-tumbuh-dan-berkembang-dikota-kediri-1(diakses pada tanggal, 5 Maret 2019).

Rangkuti, Freddy. (2008). The Power Of Brands. Jakarta. Penerbit Gramedia

Setiadi, Nugroho J.(2010).Perilaku Konsumen: Konsep Dan Impikasi Untuk Strategi Dan Penelitian Pemasaran. Jakarta. Prenada Media Group.

Shimp. T.A. (2003). Periklanan dan Promosi: Aspek tambahan Komunikasi Pemasaran Terpadu. Jakarta. Erlangga. 
Efektor, Volume 7 Issue 1, 2020, Pages 1 - 14

Gesty Ernestivita, Subagyo

Subagyo. (2013).Analysis Pengaruh Charakter, Pembelajaran dan Kompetensi wirausahawan terhadap Keunggulan Bersaing dan Kierja UMKM di Kediri. Disertasi, Universitas Merdeka Malang.

Sulianta. (2014). Jurus Promosi Online Paling Top. Jakarta. Elex Media Komputindo. 